\title{
5
}

\section{Constitutionalization and EU Employment Law}

\author{
Mark Bell
}

\section{Introduction}

One of the evident trends in European Union employment law has been a gradual shift towards the constitutionalization of key workers' rights. There are multiple interpretations of the term 'constitutionalization', but it can be linked to processes that seek to entrench certain legal norms and to attribute them with a higher status. ${ }^{1}$ This typically has the consequence that those provisions that have been constitutionalized become more difficult to amend or repeal. Moreover, if there is a conflict with other legal norms, then those that have been constitutionalized should prevail or should be accorded greater weight based on their elevated status. The process of constitutionalization is often made visible through the proclamation or adoption of legal texts that are given a special value. Most obviously, this occurs when a constitution is adopted. It can extend to other instruments that lack the label of a 'constitution', but which receive the hierarchically superior status associated with such documents. In relation to the EU, its efforts to adopt a document with the formal title of constitution may have withered, but it is clear that the founding Treaties have a constitutional function in the Union's legal order. The Treaties also illustrate the role of courts in the process of constitutionalization. The Court of Justice has described the Treaties as a 'constitutional Charter' ${ }^{2}$ and it has used them as a foundation for identifying rights that should be treated as 'fundamental' within the EU legal order, such as the rights of EU citizenship. ${ }^{3}$ The activism of the Court of Justice also reveals how courts may be inventors of constitutionalization even in the absence of formal legal texts pursuing this objective. ${ }^{4}$ An example that will be considered in this chapter is the constitutional role of the unwritten general principles of EU law, which have been constructed over time by the Court of Justice.

The idea that certain rights relating to the workplace should be recognized as possessing a fundamental or constitutional character is not particularly novel. For example, the Council of Europe's 1961 European Social Charter might be described

1 Arthurs, 'The Constitutionalization of Employment Relations: Multiple Models, Pernicious Problems', 19 Social and Legal Studies (2010) 403, at 405; Christodoulisdis and Dukes, 'Labour, Constitution and A Sense of Measure: a Debate with Alain Supiot', 19 Social and Legal Studies (2010) 217 , at 218 .

2 Opinion 1/91 on the draft agreement between the Community, on the one hand, and the countries of the European Free Trade Association, on the other, relating to the creation of the European Economic Area [1991] ECR I-6079, Rec. 1 of judgment.

3 Shaw, 'Citizenship: Contrasting Dynamics at the Interface of Integration and Constitutionalism', in P. Craig and G. de Búrca (eds), The Evolution of EU Law (2011) 574.

4 Fudge, 'Constitutionalizing Labour Rights in Europe', in T. Campbell and K. Ewing (eds), The Legal Protection of Human Rights (2011) 244. 
as reflecting a form of constitutionalization; the signatories agreed to adhere to a set of minimum standards in terms of workers' rights, thereby fettering their discretion to alter employment law in a manner that dipped below the catalogue of rights guaranteed by the Charter (at least in principle if not in practice). In relation to the EU, a clear signal of the trajectory towards the constitutionalization of employment rights can be found in the 1989 Community Charter of the Fundamental Social Rights of Workers. The preamble of this document describes it as a 'solemn proclamation', but it is not legally binding. Nevertheless, the decision by the member states ${ }^{5}$ to cloak the revitalization of European social policy in the language of a 'Charter', and its reference to 'fundamental' rights, has been subsequently interpreted by the Court of Justice as an indication of its special legal value. The Court has deployed the 1989 Charter as a means of identifying employment rights that warrant extra protection, or more intense judicial scrutiny of any departures from these rights. ${ }^{6}$ The idea of enshrining fundamental workers' rights in a document of constitutional significance is reflected even more forcefully in the EU Charter of Fundamental Rights, ${ }^{7}$ which now enjoys the same legal status as the Treaties. ${ }^{8}$

This chapter explores the process and effects of constitutionalization within EU employment law and reflects upon its impact on the substantive content of this area of law. The first section begins by examining how constitutionalization has evolved. It considers the tension between constitutionalization and the autonomy of parties to the contract of employment, as well as the reasons for the tendency to embody certain workers' rights with a higher legal status. The second section looks at a specific example of constitutionalization within employment law: the case of EU equality law. This is an area where both the courts and the legislator have recognized that the legal norms engage fundamental principles of law, including the protection of human rights. This impacts upon the Court's interpretation of equality legislation, with some recent decisions emphasizing that the constitutional rights and principles are superior and free-standing sources of law, which reach beyond the contents of the equality directives. The final section of this chapter considers an area of employment law where the engagement of constitutional rights is more ambiguous: the personal scope of employment rights. In order to access most employment rights, it must first be recognized that the activity performed was in the context of an employment relationship. In short, many employment rights are only extended to those deemed to be 'workers' or falling into associated categories. ${ }^{9}$ The person who is genuinely self-employed will, in most cases, not be entitled to the protection of employment law. The apparent simplicity of this binary divide is misleading; disentangling the complexity of modern working relationships is a conundrum that challenges most European legal systems. ${ }^{10}$ The final section of this chapter re-examines this issue through the lens of constitutionalization. This is an aspect of employment law that is not commonly associated

\footnotetext{
5 The Charter was originally signed by only 11 of the then 12 member states (the UK being the exception).

6 See further section 2 of this chapter.

8 Art. 6(1) TEU.

9 Legal systems adopt different terminology in this field. For example, in the UK, there is an important legal distinction between 'employees' and 'workers'. For the purposes of this chapter, 'worker' will be adopted as a generic term to capture broadly the personal performance of work; it is not intended to reflect any particular national definition of this legal category.

10 Veneziani, 'The Employment Relationship', in B. Hepple and B. Veneziani (eds), The Transformation of Labour Law in Europe (2009) 99.
} 
with fundamental rights; the notion of a right to be treated as a worker is not expressly found in most fundamental rights instruments. Therefore, this section will explore whether the process of constitutionalization has relevance or effect even where there is the absence of a clearly applicable fundamental social right.

\section{Constitutionalization and the Employment Relationship}

The pace with which constitutionalization has established itself within the sphere of employment means that there is a temptation to take it for granted that the employment relationship is an appropriate venue for the application of constitutional rights and principles. Yet standing back from current legal developments, this is not immediately obvious. Private law typically views the employment relationship through the prism of the contract of employment. Broadly speaking, the contract is an agreement between the worker and the employer for the provision of labour in exchange for remuneration and the acceptance by the worker of some degree of subordination to the managerial requirements of the employer. ${ }^{11}$ Classically, the private law perspective on the employment contract begins with the principle of freedom of contract; the employer and worker are free to negotiate the terms of their agreement without external interference. ${ }^{12}$ Freedom of contract in the employment sphere disguises, however, the inequality of bargaining power between the two parties. In most cases, the potential worker has a greater dependence on the employer than vice versa. The employer may be able to offer contractual terms on a 'take it or leave it' basis, with no genuine possibility for the worker to renegotiate the terms. The economic power of the employer, especially in sectors where the supply of workers exceeds demand from employers, creates a risk of exploitation on the part of the dominant party to the contract and this has resulted in legal intervention to rebalance the bargaining power of the parties. Notably, there has been statutory intervention to regulate working conditions; workplace health and safety was often an initial field where the state felt it was not sufficient to rely on freedom of contract in order to secure adequate protection of workers' interests. ${ }^{13}$ Collins suggests that the extensiveness of social regulation of employment now tends to overshadow its private law origins. ${ }^{14}$ At the same time, state intervention has often been directed towards strengthening the negotiating power of workers by facilitating their collective organization through trade unions and encouraging processes of collective bargaining. In the light of such interventions, it is clear that the 'privacy' of the employment contract has long been subject to direct or indirect intrusion by the state. Indeed, contemporary debates about the extensiveness of EU employment law tend to be more dominated by concern for the economic consequences of further regulation rather than principled objections to the erosion of the freedom of contract.

While state intervention in the employment relationship is commonplace, this can be distinguished from the trend towards constitutionalization. Not all forms of legal

\footnotetext{
11 While the approach to defining the employment relationship varies across member states, these two elements are the focus of the approach of the Court of Justice to whether someone enjoys the status of 'worker': e.g. Case C-232/09, Danosa v LKB Lizings SIA, judgment of 11 November 2010, not yet published, Rec. 39.

12 Collins, 'Justifications and Techniques of Legal Regulation of the Employment Relation', in H. Collins, P. Davies, and R. Rideout (eds), Legal Regulation of the Employment Relation (2000) 3, at 6.

13 E.g. P. Davies and M. Freedland, Labour Legislation and Public Policy (1993), at 35.

14 Collins, supra note 12, at 7.
} 
intervention have the character of constitutionalization; it would be an overextension of this concept to suggest that any legislation that impinged upon the employment relationship implied constitutionalization. There is, therefore, a distinction to be drawn between 'ordinary' legislation and that which has been constitutionalized. Where the rights at stake are housed within a constitutional-type document, the bifurcation is visible; within the EU context, there is an evident intention that the employment rights located in the Charter of Fundamental Rights should receive a higher legal status than employment rights found only in secondary legislation, such as regulations and directives. The Court has already annulled elements of secondary legislation in conflict with the Charter, illustrating its hierarchical superiority. ${ }^{15}$ Nevertheless, it would be too simplistic to view constitutionalization purely in terms of the location of legal provisions. Through the interpretation of the courts, it may be possible that elements of secondary legislation are deemed to have a special legal significance, which leads, in effect, to a constitutionalization of these norms. Mantouvalou links this to the extent to which economic considerations are deemed to be a legitimate basis for the restriction of the protection of workers; where rights have been constitutionalized, then this should counter arguments that seek to curtail rights based on cost considerations. ${ }^{16}$ An example of this type of reasoning can be found within the Court's case law on gender equality at work, where it has opposed the argument that economic factors may form an explicit basis for restricting equal treatment:

to concede that budgetary considerations may justify a difference of treatment between men and women which would otherwise constitute indirect discrimination on grounds of sex would mean that the application and scope of a rule of Community law as fundamental as that of equal treatment between men and women might vary in time and place according to the state of the public finances of Member States. ${ }^{17}$

The prohibition of indirect discrimination was only expressly found within secondary legislation, but this did not prevent the Court from attributing it with a higher legal status due to its connection to one of the fundamental principles of EU law (equal treatment of women and men).

While gender equality is an obvious example of constitutionalization within the Court's reasoning, it is also clear that there are some areas of EU employment law where the Court has not identified a nexus with the protection of fundamental rights and where economic reasons for restricting rights are not overtly excluded. The Acquired Rights Directive ${ }^{18}$ offers an example in this regard. Hepple has argued that the approach of the Court in this area has been conservative in comparison to its gender equality case law. ${ }^{19}$ While there is acknowledgement of the protective objectives of the legislation, ${ }^{20}$

15 Case C-236/09, Association Belge des Consommateurs Test-Achats ASBL and Others $v$ Conseil des ministres, judgment of 1 March 2011, not yet published.

16 Mantouvalou, 'Human Rights for Precarious Workers: the Legislative Precariousness of Domestic Labour', 33 Comparative Labor Law and Policy Journal (2012) 133.

17 Case C-226/98, Jorgensen v Foreningen af Speciallager and Sygesikringens Forhandlingssugvalg [2000] ECR I-2447, Rec. 39 of judgment. See further, Schiek, 'Indirect Discrimination', in D. Schiek, L. Waddington, and M. Bell (eds), Cases, Materials and Text on National, Supranational and International Non-Discrimination Law (2007) 323, at 453.

18 Council Directive 2001/23, OJ 2001 L 82/16, on the approximation of the laws of the Member States relating to the safeguarding of employees' rights in the event of transfers of undertakings, businesses or parts of undertakings or businesses.

19 Hepple, 'The Implementation of the Community Charter of Fundamental Social Rights', 53 $\operatorname{MLR}(1990) 643$, at 649.

20 E.g. Case C-392/92, Schmidt v Spar- und Leihkasse der fruheren Amter Bordesholm, Kiel und Cronshagen [1994] ECR I-1311, Rec. 15 of judgment; Case C-108/10, Scattolon v Ministero dell'Istruzione, dell'Università e della Ricerca, judgment of 6 September 2011, not yet published, Rec. 58. 
the Court's judgments on the Acquired Rights Directive rarely identify provisions of the legislation as impinging upon the fundamental rights of workers. Moreover, its case law does not suggest that there is a particular priority attached to the protection of workers' rights as opposed to balancing these with the economic interests of employers. ${ }^{21}$

Having identified a distinction between 'ordinary' and 'constitutionalized' employment law, the question arises as to why there is a need to move from one category to the other. If the rationale for state intervention in the freedom of contract was to redress the inequality of bargaining power between the employer and the worker, then what underpins the further incursion into contractual freedom by the application of constitutional norms into private relationships?

\section{A. Rationales for Constitutionalizing Employment Law}

From a historical perspective, Dukes argues that the law has long been concerned with establishing an 'industrial constitution', based around the 'replacement of the individual negotiation of terms and conditions with universal collective bargaining. ${ }^{22}$ By guaranteeing freedom of association and the right to engage in collective bargaining or to take collective action, the state provides a framework for industrial democracy, whereby workplace relations are founded on dialogue and negotiation between employers and workers. The state entrenches the basic facets of this system, such as the freedom to form and join a trade union, but the substantive outcomes in terms of pay and working conditions are left for the parties to determine. In this model, the law might be viewed as supplanting individuals' freedom of contract with a collectivized understanding of freedom of contract. A classic example of this would be the 'laissez-faire' model of employment law that pertained in the United Kingdom for a large part of the twentieth century. The state generally refrained from statutory regulation of working conditions, but intervened to facilitate collective bargaining as the principal source of workplace regulation. ${ }^{23}$

There is some evidence of this model influencing EU law, where a constitutional footing (in the form of the founding Treaties) has been given to social dialogue between management and labour, which may lead to legally binding agreements. ${ }^{24}$ Yet social dialogue has never been the pre-eminent source of regulation within EU employment law and the greater part of the legislation stems from political bargaining within the EU institutions, rather than European collective bargaining. More generally, relying on the industrial constitution as the primary route to securing a fair balance between the interests of employers and workers has been challenged by the decline, in some countries, of the vitality of collective bargaining. ${ }^{25}$ This is frequently associated with the spread of globalization. Specifically, the footloose nature of modern capital, and the persistent threat of transnational relocation, ${ }^{26}$ exercises a downward pressure on labour standards

21 E.g. Case C-463/09, CLECE SA v Socorro Martín Valor, Ayuntamiento de Cobisa, judgment of 20 January 2011, not yet published; Case C-386/09, Briot v Randstad Interim, Sodexho SA, Council of the $E U$, judgment of 15 September 2010, not yet published; Davies, 'Taken to the Cleaners? Contracting Out of Services Yet Again', 26 Industrial Law Journal (ILJ) (1997) 193, at 195; C. Barnard, EC Employment Law (3rd ed.; 2006), at 670-671.

22 Dukes, 'Constitutionalizing Employment Relations: Sinzheimer, Kahn-Freund, and the Role of Labour Law', 35 Journal of Law and Society (2008) 341, at 342; Rödl, 'Re-thinking Employment Relations in Constitutional Terms', 19 Social and Legal Studies (2010) 241, at 242.

23 Dukes, supra note 22, at 358. 24 Arts 154-155 TFEU.

25 Jacobs, 'Collective Labour Relations', in B. Hepple and B. Veneziani (eds), The Transformation of Labour Law in Europe (2009) 201, at 224-225.

26 Dukes, supra note 22, at 341; A. Somek, Engineering Equality: An Essay on European Anti-Discrimination Law (2011), at 39. 
that cannot be adequately resisted within national frameworks of collective bargaining. Fudge notes that one feature of globalization has been the spread of neoliberal economic policies via international agreements. ${ }^{27}$ These are, in themselves, a type of constitutionalization as they seek to institutionalize free trade in goods and services and they curtail the capacity of participating states to maintain domestic social regulations that are characterized as obstacles to trade. The tendency to embed these rules at the international level implies that an effective project for the constitutionalization of employment rights must also engage at this level. ${ }^{28}$ The EU is a prime example of free market principles being constitutionalized at supranational level and it is clear that these have the potential to overwhelm national social policy objectives, including measures for the protection of workers. ${ }^{29}$ Consequently, the constitutionalization of employment rights within the EU legal order becomes a means of counteracting the challenge to labour standards presented by competition within the Internal Market.

A further motivation for the turn towards constitutionalization can be found within changes in the nature of employment relationships. A widely documented trend has been the growth in 'atypical' or 'non-standard' forms of work, such as fixed-term or agency work. ${ }^{30}$ These represent a departure from the 'standard' model of a worker employed on a full-time, indefinite contract with stable working hours, and where the person for whom the worker performs work is also the employer. This tendency of fragmentation in labour market relationships poses challenges for the traditional model of protecting workers through the industrial constitution and its dependence on trade union representation. In part, this may be due to the ephemeral nature of such jobs, but it also concerns the ambiguity surrounding the legal status of these employment relationships, such as the identity of the employer or whether the individuals are workers or self-employed. Constitutionalization may offer a response to the complexity of the modern labour market in so far as it aims 'to recast labour standards as international human rights'. ${ }^{31}$ The value for non-standard workers of moving to the language of human rights lies in the potential for greater flexibility with regard to the personal scope of the application of these rights. Within ordinary employment legislation, individuals often need to establish as a prerequisite that they are an 'employee' or a 'worker' for the purposes of the legislation. This can be a stumbling block for those where the relationship is with more than one actor, such as outsourced labour, or where there is a high level of flexibility in the arrangement of work, such as 'on-demand' workers. Human rights, with their universalistic outlook, may offer a means of circumventing technical debates around the categorization of the form of employment relationship. This possibility is examined in more depth in section 5 of this chapter.

Finally, another factor propelling the rise of constitutionalization is a desire to fill the institutional gap left by the perceived decline in the strength of trade unions and

27 Fudge, supra note 4, at 246-247. $\quad 28$ Ibid., at 244; Collins, supra note 12, at 15.

29 E.g. Davies, 'Market Integration and Social Policy in the Court of Justice', 24 ILJ (1995) 49; Syrpis and Novitz, 'Economic and Social Rights in Conflict: Political and Judicial Approaches to their Reconciliation', 33 ELRev (2008) 411, at 426.

30 Kalleberg, 'Precarious Work, Insecure Workers: Employment Relations in Transition', 74 American Sociological Review (2009) 1, at 7; Rodgers, 'Precarious Work in Western Europe: the State of the Debate', in G. Rodgers and J. Rodgers (eds), Precarious Jobs in Labour Market Regulation: the Growth of Atypical Employment in Western Europe (1989) 1; Fudge and Owens, 'Precarious Work, Women, and the New Economy: the Challenge to Legal Norms', in J. Fudge and R. Owens (eds), Precarious Work, Women, and the New Economy: the Challenge to Legal Norms (2006) 3.

31 Fudge, supra note 4, at 248. 
collective bargaining. ${ }^{32}$ Converting employment rights into 'fundamental' or 'human' rights shifts the focus away from protecting workers via collective organization, and towards an enhanced role for courts and litigation. ${ }^{33}$ While litigation strategies may be collective in nature, most commonly they reflect an individualization of disputes focusing on the specific situation of the particular litigants. ${ }^{34}$ This seems to echo the transformation of employment relationships; the rise of non-standard work, and diversity in where and how work is performed, portrays an image of a labour market of individuals where bonds of solidarity between workers may have declined. ${ }^{35}$ Whether courts offer a productive alternative to the traditional channels for promoting workers' interests remains highly contested. Arthurs is critical of this approach pointing out the practical constraints of litigation (such as delay and expense), as well as the historic conservatism of courts and their frequent reluctance to challenge vested economic interests. ${ }^{36}$ Alternatively, Gearty suggests that the inclination to fall back on courts reflects an 'impatience with politics' ${ }^{37}$ Yet given the prominent role of judicial bodies as mechanisms for enforcing free trade under international agreements, arguably they have already become central actors in regulating workers' rights, in particular where these collide with economic liberalization. While the constitutionalization of employment rights does not guarantee a particular social outcome, it is, at least, an attempt to persuade courts to temper market liberalization through recognition of other fundamental objectives.

It is also possible, although not inevitable, that courts may counter individualization through recognition of collective rights as human rights. There is some evidence of this trend within the recent case law of the European Court of Human Rights. The Strasbourg Court has demonstrated an increasing willingness to interpret the European Convention on Human Rights in the light of principles emerging from the European Social Charter and the Conventions of the International Labour Organization. Notably, this led to a shift in its case law on the meaning of Article 11 on freedom of association towards recognition that this could encompass rights to engage in collective bargaining or (in some circumstances) to take industrial action. ${ }^{38}$ In contrast, this trajectory is less evident in the recent case law of the Court of Justice. In a series of cases that involved clashes between the aims of economic liberalization and, broadly speaking, social rights, the Court appeared to lean in favour of removing obstacles to trade within the EU Internal Market. ${ }^{39}$ Although the decisions included rhetorical recognition from the Court that collective action was a fundamental right, the process of balancing this against economic freedoms tended to give more weight to the latter. ${ }^{40}$

\footnotetext{
32 NovitzandFenwick, 'The Application of Human Rights Discourse to Labour Relations: Translation of Theory into Practice', in C. Fenwick and T. Novitz (eds), Human Rights at Work: Perspectives on Law and Regulation (2010) 1, at 2.

33 Arthurs, supra note 1, at 405-406; Fudge, supra note 4, at 249.

34 Gearty, 'Against Judicial Enforcement', in C. Gearty and V. Mantouvalou (eds), Debating Social Rights (2011) 1, at 35 .

35 A. Ross, Nice Work If You Can Get It: Life and Labor in Precarious Times (2009), at 5.

36 Arthurs, supra note 1, at 406.

37 Gearty, supra note 34, at 34.

38 Seefurther, Ewing and Hendy, 'The Dramatic Implications of Demir and Baykara', 39 ILJ(2010) 2.

39 Case C-341/05, Laval un Partneri Ltd v Svenska Byggnadsarbetareförbundet [2007] ECR I-11767; Case C-438/05, International Transport Workers' Federation, Finnish Seamen's Union v Viking Line ABP, OÜ Viking Line Eesti [2007] ECR I-10779; Case C-346/06, Rüffert v Land Niedersachsen [2008] ECR I-1989.

40 Syrpis, 'Reconciling Economic Freedoms and Social Rights-The Potential of Commission v Germany (Case C-271/08, Judgment of 15 July 2010)', 40 ILJ (2011) 222.
} 


\section{The Evolution of Constitutionalization within EU Employment Law}

Having discussed the nature and rationale for constitutionalization within employment law, this section provides a short overview of the principal ways in which this trend has been manifested within EU employment law. A loose distinction can be drawn between forms of constitutionalization that have been (1) forged through judicial creativity or (2) founded on new or amended legal texts, such as charters and treaties. While the two are obviously interrelated, in the former the courts have been the leading architects, whereas in the latter the member states have taken the driving seat.

\section{A. Constitutionalization by the Courts}

Looking back at the original Treaties, these famously included the right to equal pay for women and men ${ }^{41}$ and it could be argued that this was a nascent form of constitutionalization. Yet the enforceability of this provision was, at best, unclear and it was not anticipated by the member states that a provision of an international trade agreement could be applied directly into private employment contracts. ${ }^{42}$ As is well known, that changed through the Court of Justice's innovatory concept of 'direct effect', allowing individual rights found within the Treaties to be enforced in national courts. In Defrenne $v$ SABENA (no. 2), ${ }^{43}$ the Court not only confirmed that this applied to the right to equal pay, but that the enforceability of this provision 'also extends to all agreements which are intended to regulate paid labour collectively, as well as to contracts between individuals' ${ }^{44}$ This inaugurated a new restriction on the contractual autonomy of parties to the employment relationship; henceforth, private employment contracts were subject to the restrictions imposed by national legislation and directly effective rights found within the founding treaties.

In general, the idea of freedom of contract in relation to the workplace does not appear to have exercised a significant influence on the Court's consideration of whether it is appropriate to apply Treaty provisions in the context of private employment relationships. In Angonese, ${ }^{45}$ it confirmed that its reasoning in Defrenne $v$ SABENA extended to the prohibition of nationality discrimination between EU citizen workers ${ }^{46}$ and consequently this could be applied between private persons (on the facts of the case, between a job applicant and a private sector bank). ${ }^{47}$ More controversially, the Court has also held that the Treaty Internal Market provisions can be applied to the actions of trade unions. In Laval, ${ }^{48}$ the Court held that Article $49 \mathrm{EC}^{49}$ on the free movement of services could be applied to collective action by trade unions where this could create obstacles to the cross-border provision of services. Similarly, in Viking, ${ }^{50}$ the Court was

41 Art. 119 EEC, now Art. 157 TFEU.

42 P. Craig and G. de Búrca, EU Law-Text, Cases and Materials (5th ed.; 2011), at 185.

43 Case 43/75, Defrenne II [1976] ECR $455 . \quad 44$ Ibid., Rec. 39.

45 Case C-281/98, Angonese v Cassa di Risparmio di Bolzano SpA [2000] ECR I-4139.

46 Former Art. 39 EC, now Art. 45(2) TFEU.

47 Angonese, supra note 45, at Rec. 36.

48 Case C-341/05, Laval un Partneri Ltdv Svenska Byggnadsarbetareförbundet [2007] ECR I-11767, Recs 98-99.

49 Now Art. 56 TFEU.

50 Case C-438/05, International Transport Workers' Federation, Finnish Seamen's Union v Viking Line ABP, OÜ Viking Line Eesti [2007] ECR I-10779, Recs 33-37. 
willing to apply Article $43 \mathrm{EC}^{51}$ on freedom of establishment to collective agreements and collective action.

In addition to the horizontal application of Treaty provisions, the Court's case law on general principles of law has been another route through which constitutional norms impact upon employment relationships. The general principles are unwritten; they are not catalogued within the Treaties. Nevertheless, they form a basis for judicial review of EU secondary legislation, as well as acts of the Union's institutions or of the member states when acting within the scope of EU law. ${ }^{52}$ Amongst the general principles, two seem to be especially pertinent to employment: the principle of equal treatment and/ or non-discrimination, and the principle of respect for fundamental rights. The general principle of equal treatment 'requires that comparable situations must not be treated differently and that different situations must not be treated in the same way unless such treatment is objectively justified'. ${ }^{53}$ This imposes a basic test of fairness or rationality; arbitrary distinctions in the treatment of similarly situated workers may fall foul of this requirement. For example, in Rodriguez Caballero, the Court of Justice found a breach of the general principle of equal treatment where workers who were unfairly dismissed and whose employer subsequently became insolvent were not entitled to a benefit that was otherwise available to unfairly dismissed workers whose employers were not insolvent. ${ }^{54}$ Notably this case arose in the context of Spanish implementation of a directive on the protection of employees in the event of the employer's insolvency. ${ }^{55}$ The judgment does not suggest that the content of the directive per se engaged fundamental rights; this seems to be a good example of 'ordinary' employment legislation. Yet the transposition of the directive brought the national implementing measures into the scope of EU law, thereby triggering the requirement to comply with the general principle of equal treatment. ${ }^{56}$

Another aspect of the Court's case law is the general principle of respect for fundamental rights. This forms a bridge to international human rights law and the Court has regularly acknowledged that its interpretation of the general principle is based on such instruments. This is now codified in Article 6(3) TEU:

Fundamental rights, as guaranteed by the European Convention for the Protection of Human Rights and Fundamental Freedoms and as they result from the constitutional traditions common to the Member States, shall constitute general principles of the Union's law.

The employment law relevance of the general principle of respect for fundamental rights arises from the way in which the Court has identified certain elements of EU employment legislation that are, in its view, inherently concerned with the protection of fundamental rights. This has been most visible in relation to EU equality Directives. While this is examined in more depth in section 4 of this chapter, Schröder provides a good example of how this can be seen to affect the way in which the Court interprets the legislation. In this case, the Court rejected an argument that the retrospective award of equal pay to

51 Now Art. 49 TFEU. $\quad 52$ See further the discussion in section 4 of this chapter.

53 Case C-149/10, Zoi Chatzi v Ypourgos Oikonomikon, judgment of 16 September 2010, not yet published, Rec. 64; see also, Case C-81/05, Cordero Alonso v Fondo de Garantía Salarial [2006] ECR I-7569, Rec. 37.

54 Case C-442/00, Rodríguez Caballero v Fogasa [2002] ECR I-11915, Rec. 33.

55 Council Directive 80/987, OJ 1980 L 283/23, now replaced by Council Directive 2008/94, OJ $2008 \mathrm{~L} \mathrm{283/36}$, on the protection of employees in the event of the insolvency of the employer.

56 Rodríguez Caballero v Fogasa, supra note 54, Rec. 30. 
women who had experienced discrimination should be limited where this could place the member state concerned at a competitive disadvantage:

[I]t must be concluded that the economic aim pursued by Article 119 of the Treaty, namely the elimination of distortions of competition between undertakings established in different Member States, is secondary to the social aim pursued by the same provision, which constitutes the expression of a fundamental human right. ${ }^{57}$

As mentioned earlier, this is a vivid illustration of how constitutionalization of an employment right may help to resist arguments that its scope should be traded-off with the pursuit of economic efficiency objectives. ${ }^{58}$

\section{B. Constitutionalization through Charters and Treaties}

The constitutionalization of aspects of the employment relationship has also been the outcome of initiatives taken by the member states. Over the years, there has been a succession of amendments to the founding Treaties and these gradually shifted towards an acknowledgement that EU employment law engaged fundamental rights. ${ }^{59}$ As mentioned in the introduction, a decisive step in the direction of constitutionalization was the proclamation of the 1989 Community Charter of the Fundamental Social Rights of Workers. The Charter's contents were an unusual mix of declaratory provisions, combined with programmatic clauses. For instance, point 13 recognized that the 'right to resort to collective action in the event of a conflict of interests shall include the right to strike'; however, there was no implication that the (then) EEC could or would seek to implement this right. In contrast, point 19 states that 'every worker must enjoy satisfactory health and safety conditions' and calls for 'further harmonisation' in this field. This mixture in approach reflects the politics of the Charter; it was expressly aimed at relaunching the social dimension of European integration and it became the basis for a subsequent legislative programme by the European Commission. ${ }^{60}$ Its legacy, though, was to introduce the idea that employment rights were not simply a matter of 'ordinary' legislation; to some extent, they entailed the protection of fundamental rights.

The Charter's inference that norms of a higher legal status were at play demonstrably influenced the Court of Justice in certain subsequent cases on the interpretation of employment legislation. This is best illustrated in BECTU, ${ }^{61}$ which concerned whether employees working on short contracts (for less than 13 weeks in duration) should be entitled to the right to paid holidays found within the Working Time Directive. ${ }^{62}$ The Court took its lead from the provisions of the Charter; point 8 declared: 'every worker of the European Community shall have a right to a weekly rest period and to annual paid leave'. Accordingly, the Court held:

It follows that the entitlement of every worker to paid annual leave must be regarded as a particularly important principle of Community social law from which there can be no

57 Case C-50/96, Deutsche Telekom AGv Schröder [2000] ECR I-743, Rec. 57.

58 Mantouvalou, supra note 16; Collins, supra note 12, at 12.

59 E.g. in 1999, the Treaty of Amsterdam amended the EC Treaty to insert a reference in Art. 117 EC to the Council of Europe's European Social Charter.

60 Barnard, supra note 21, at 14.

61 Case C-173/99, Rv Secretary of State for Trade and Industry, ex parte Broadcasting, Entertainment, Cinematogaphic and Theatre Union (BECTU) [2001] ECR I-4881.

62 The original Directive was replaced with the following: Council Directive 2003/88, OJ 2003 L 299/9, concerning certain aspects of the organisation of working time. 
derogations and whose implementation by the competent national authorities must be confined within the limits expressly laid down by Directive 93/104. ${ }^{63}$

Furthermore, it firmly rejected arguments from the United Kingdom concerning the administrative costs that would be entailed for small and medium-sized undertakings; the Court noted that improvements in health and safety 'should not be subordinated to purely economic considerations' ${ }^{64}$

While the Court has continued to refer to the 1989 Charter as a guide when interpreting EU employment legislation, ${ }^{65}$ it is now overshadowed by the legally binding provisions found in the EU Charter of Fundamental Rights. A wide variety of the Charter's provisions have a potential application to the employment relationship. For example, Article 12 on freedom of association expressly refers to trade unions, while Article 5 prohibits 'forced or compulsory labour'. Titles III and IV are likely to prove the most important parts of the Charter in relation to the workplace. Title III on equality sets out a prohibition of discrimination, as well as specific provisions relating to different groups vulnerable to discrimination, such as women and people with disabilities. Title IV on solidarity has been referred to by the Court of Justice as enumerating 'fundamental social rights' ${ }^{66}$ Its provisions focus on employment: workers' right to information and consultation; the right of collective bargaining and action; the right of access to placement services; protection from unjustified dismissal; the right to fair and just working conditions; the prohibition of child labour and the protection of young workers; the reconciliation of family and professional life. ${ }^{67}$ Although these cover a broad swathe of employment law issues, they are expressed more tersely than in the 1989 Charter and certain rights are omitted altogether, most notably the right to fair remuneration. ${ }^{68}$ Compared to the extensive detail in the 31 articles of the 1996 Revised European Social Charter (of the Council of Europe), the Charter of Fundamental Rights is a rather bald statement of core workplace rights.

The brevity of the social provisions in the Charter of Fundamental Rights is balanced by the reference in its preamble to 'the Social Charters adopted by the Community and by the Council of Europe', which seems to invite the Court of Justice to continue to take these instruments into account. Indeed, in some cases the Court has referred to both the 1989 Charter and the Charter of Fundamental Rights, indicating that it still regards the former as a relevant source. ${ }^{69}$ The official explanations accompanying the Charter of Fundamental Rights are another point of reference, to which the Court of Justice is required to pay 'due regard'. ${ }^{70}$ The explanations connect the Charter of Fundamental Rights to specific elements of EU employment legislation. For example, they describe Article 31 on fair and just working conditions as being 'based on' the Working Time Directive and the Framework Directive on health and safety. ${ }^{71}$ This is significant because it flags up the constitutional relevance of such directives given their characterization as the expression of a right found in the Charter.

63 BECTU, supra note 61, Rec. $43 . \quad{ }^{64}$ Ibid., Rec. 59.

65 E.g. Case C-303/06, Coleman v Attridge Law and Law [2008] ECR I-5603, at Rec. 43; Zoi Chatzi, supra note 53, Rec. 36.

66 Zoi Chatzi, note 53, at Rec. 37.

67 Arts 27-33.

68 Point 5, 1989 Charter.

69 E.g. Case C-341/05, Laval, supra note 48, at Rec. 90; Case C-149/10, Zoi Chatzi, supra note 53, at Recs 36-37.

70 Preamble to the Charter of Fundamental Rights. See further: Explanations relation to the Charter of Fundamental Rights, OJ 2007 C 303/17.

71 Council Directive 2003/88, OJ 2003 L 299/9 and Council Directive 89/391, OJ 1989 L 183/1. 
In the initial period following the signing of the Charter of Fundamental Rights in 2000 , but prior to it becoming legally binding in 2009, the Court of Justice was tentative in its use of the Charter. In BECTU, for instance, the Court refrained from referring to the Charter, even though this had been used by the Advocate General as an interpretative tool. ${ }^{72}$ This situation has now changed, but the limited body of case law allows few conclusions to be drawn on the eventual impact of the Charter throughout employment law. As discussed in the following section, some recent case law in the field of equality has provided an initial insight into the way in which the Charter may contribute to the tendency to constitutionalize employment law. The mere fact that the Charter includes an inventory of employment rights alongside the well-established catalogue of civil and political rights is already a powerful signal that the protection of workers is not simply a matter of 'ordinary' legislation that can be freely changed according to the current political climate. While it would be an overstatement to suggest that the Charter converts every element of employment law into legislation of constitutional significance, it sets basic parameters and implies that there is an irreducible minimum of worker protection that must be guaranteed. For example, Article 27 provides that 'workers or their representatives must, at the appropriate levels, be guaranteed information and consultation in good time in the cases and under the conditions provided for by Community law and national law and practices'. This leaves a broad margin of discretion for the legislator as to how this right should be operationalized, but it would appear to exclude the possibility that the legislator could subsequently decide to deregulate this field by eliminating any duties on employers to engage in information and consultation.

Having introduced the concept of constitutionalization and examined evidence of how it has evolved within EU employment law, the remainder of the chapter examines two issues in employment law in order to assess the impact of constitutionalization: equality, and the personal scope of employment rights.

\section{Constitutionalization via General Principles of Law: EU Equality Directives}

This section of the chapter takes a specific area of EU employment law in order to look in more depth at the process of constitutionalization. EU equality law has expanded greatly over time and it is a major constraint on contractual freedom in relation to the workplace. An employer cannot, for example, take into account characteristics such as ethnic origin or sexual orientation in choosing which persons to offer employment contracts to, nor in the terms of those contracts. The mere existence of equality legislation is not, though, evidence by itself of constitutionalization; it could be akin to any other form of statutory regulation of the labour market. Instead, evidence of constitutionalization arises from the elevated status that the EU courts have attached to equality legislation and, latterly, the reflection of this process within the provisions of equality directives. This section begins by examining how workplace equality rights were constitutionalized, followed by analysis of recent equality case law which suggests a new turn in the constitutionalization process. 


\section{A. Constitutionalizing Equality Legislation}

From today's standpoint, it may seem obvious that employment equality legislation has a constitutional relevance in so far as it is an expression of the fundamental right to equal treatment and freedom from discrimination. Yet the starting premise of EU equality law was not the protection of fundamental rights. As is well documented, the rationale for Article 119 EEC on equal pay for women and men was concern that the exploitation of cheap female labour in some member states could provide an unfair competitive advantage within the common market. ${ }^{73}$ During the 1970 s, the first wave of EU social legislation was adopted, including Directive $75 / 117^{74}$ on equal pay and Directive $76 / 207^{75}$ on equal treatment in employment. These instruments were alongside other Directives on collective redundancies ${ }^{76}$ and the transfer of undertakings. ${ }^{77}$ Examining the language of these initial employment law Directives, there is little evidence that they were imagined as instruments for the protection of fundamental social rights. The preamble of the 1975 Equal Pay Directive refers to 'the establishment and functioning of the common market' as its rationale and this is also the approach found within the Directives on collective redundancies and the transfer of undertakings. It is only the 1976 Equal Treatment Directive that does not place itself explicitly within the framework of market-making objectives; its preamble evokes a broader goal of improving living and working conditions. The predominant emphasis on economic objectives reflects the limited legal competence of the EEC for social legislation and the need to present such measures as furthering the completion of the common market.

The initial push to reconceptualize equality legislation as having a higher legal significance can be traced to the case law of the Court of Justice. In Defrenne v SABENA (III), it gave an unambiguous signal regarding its perspective:

The Court has repeatedly stated that respect for fundamental personal human rights is one of the general principles of Community law, the observance of which it has a duty to ensure. There can be no doubt that the elimination of discrimination based on sex forms part of those fundamental rights. ${ }^{78}$

The recognition of the connection between human rights protection and gender equality law is not a theme that the Court has frequently explored in subsequent case law, but there are occasions where this appears to tip the balance in favour of an expansive reading of the legislation. The most visible example is the case law on discrimination relating to gender reassignment. In $P v S$, the Court falls back on human rights-based reasoning to explain why discrimination against a transgender man constitutes sex discrimination: 'to tolerate such discrimination would be tantamount, as regards such a person, to a failure to respect the dignity and freedom to which he or she is entitled, and which the Court has a duty to safeguard'.$^{79}$ In two subsequent cases, the Court was confronted with situations of inequality in employment and social security benefits related to the inability of the individuals concerned to alter their birth certificates to reflect their actual gender

73 D. Hoskyns, Integrating Gender-Women, Law and Politics in the European Union (1996), at 49; Fredman, 'Discrimination Law in the EU: Labour Market Regulation or Fundamental Social Rights', in H. Collins, P. Davies, and R. Rideout (eds), Legal Regulation of the Employment Relation (2000) 183, at 185 .

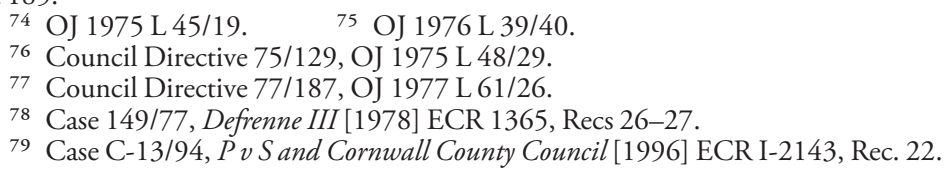


identity. The Court eschewed a formalistic interpretation of gender equality legislation and instead concentrated on the underlying principles, holding that there was inequality of treatment connected to the breach of the individuals' human rights. ${ }^{80}$

The Court's willingness to decouple equality legislation from market regulation objectives has been gradually reflected in alterations to the legal framework. This shift in paradigm emerges clearly following the 1999 amendments to the EC Treaty. A new Article 3(2) was added setting an autonomous objective for the Union of eliminating inequalities and promoting equality between women and men. ${ }^{81}$ Furthermore, the competence of the EC for combating discrimination was extended to cover the grounds of racial or ethnic origin, religion or belief, age, disability, and sexual orientation. ${ }^{82}$ This led to a new generation of equality legislation where the human rights foundation of the law is expressly acknowledged. ${ }^{83}$ The preambles of the 2000 Racial Equality and Employment Equality Directives cite a wide range of international human rights treaties, the European Convention on Human Rights (ECHR) and common constitutional principles as part of their explanatory rationale. ${ }^{84}$ In a similar vein, the 2006 'Recast' Gender Directive, which consolidates much of the legislation relating to gender equality in employment, cites in its preamble the 'fundamental principle' of equality between men and women and the relevant provisions of the EU Charter of Fundamental Rights. ${ }^{85}$ This tendency to equate equality legislation with the protection of fundamental rights, in particular international human rights, begins to set it apart from other types of EU employment legislation. For example, the 1970s directives on collective redundancies and the transfer of undertakings were replaced with revised versions in 1998 and 2001 respectively. ${ }^{86}$ While the preambles of both now mention the 1989 EC Social Charter, their legal foundation remained the furtherance of the Internal Market. ${ }^{87}$ Based purely on an analysis of the text of the directives, it would be hard to escape the conclusion that the legislator viewed the directives on equality as bearing a greater significance for fundamental rights protection than those on redundancies and the transfer of undertakings. ${ }^{88}$

\section{B. General Principles as an Autonomous Source of Rights?}

The process discussed above portrays constitutionalization as a method that impacts on the way in which law is interpreted and understood. Specifically, it has allowed the Court

80 Case C-117/01, KB v NHS Trust Pensions Agency [2004] ECR I-541; Case C-423/04, Richards $v$ Secretary of State for Work and Pensions [2006] ECR I-3585. See further, Bell, 'Gender Identity and Sexual Orientation: Alternative Pathways in EU Equality Law', 60 American Journal of Comparative $\operatorname{Law}(2012) 127$.

81 Now Art. 8 TFEU. $\quad 82$ Art. 19 TFEU (former Art. 13 EC).

83 Schiek, 'A New Framework on Equal Treatment of Persons in EC Law?', 8 ELRev (2002) 290.

84 Recs 2 and 3, Council Directive 2000/43, OJ 2000 L 180/22, implementing the principle of equal treatment between persons irrespective of racial or ethnic origin; Recs 1 and 4, Council Directive 2000/78, OJ 2000 L 303/16, establishing a general framework for equal treatment in employment and occupation.

85 Recs 2 and 5, Council Directive 2006/54, OJ 2006 L 204/23, on the implementation of the principle of equal opportunities and equal treatment of men and women in matters of employment and occupation (recast).

${ }^{86}$ Council Directive 98/59, OJ 1998 L 225/16, on the approximation of the laws of the Member States relating to collective redundancies; Council Directive 2001/23, supra note 18.

87 The Directives were based on Art. 94 EC (now Art. 115 TFEU).

88 E.g. the Collective Redundancies Directive could have been linked to the protection of the right to information and consultation found within Art. 29 of the 1996 Revised European Social Charter, but this is not mentioned in the Directive's preamble. 
to adopt an expansive reading of equality directives and to lead the law in unanticipated directions, such as the case law on gender reassignment. Nonetheless, the existence of secondary legislation remains crucial because this is the conduit through which general principles of law can take effect. At an early stage, the Court of Justice appeared to exclude the possibility that general principles could have an autonomous force in the absence of any substantive legal provisions. In Defrenne $v$ SABENA (III), the Court considered the airline's contractual term requiring female cabin attendants to retire at the age of 40; no such term was included in the contracts of male cabin attendants. ${ }^{89} \mathrm{It}$ concluded that discrimination in retirement ages could not be characterized as a violation of the right to equal pay and, at the relevant time, there was no EEC legislation prohibiting discrimination in working conditions between women and men. The question arose, therefore, whether the general principle of equality within Community law could be relied upon as an autonomous source of rights for Ms Defrenne in relation to her discriminatory dismissal. This was rejected by the Court on the basis that:

the Community had not, at the time of the events now before the Belgian courts, assumed any responsibility for supervising and guaranteeing the observance of the principle of equality between men and women in working conditions other than remuneration. ${ }^{90}$

This point of law arose again in the 1998 case of Grantv South-West Trains. ${ }^{91}$ The crux of the case was a contractual benefit providing free rail travel to employees and their partners, provided that the employee was either married or had been in a relationship with an opposite-sex partner for more than two years. This excluded Ms Grant's same-sex partner. While the case primarily turned on whether her treatment could be construed as less favourable treatment on grounds of sex (which the Court rejected), an alternative legal argument was that discrimination based on sexual orientation was contrary to the general principle of respect for fundamental rights and that this could be directly applied to the contract of employment. The Court resisted the apparent attempt to give autonomous force to fundamental rights within EC law:

[A]lthough respect for the fundamental rights which form an integral part of those general principles of law is a condition of the legality of Community acts, those rights cannot in themselves have the effect of extending the scope of the Treaty provisions beyond the competences of the Community. ${ }^{92}$

At this juncture, it appears to be a settled position that employees cannot derive free-standing rights from the general principles of EU law, such as respect for fundamental rights. The only exception to this position was with regard to employees of the EU institutions. This distinction is based on the Court's view that the legality of the acts of the Union's institutions are subject to compliance with the general principles of law and this extends to situations when the Union acts as an employer. ${ }^{93}$

The role played by general principles of law was thrust into controversy by the Court's 2005 decision in Mangold $v$ Helm. ${ }^{94}$ The case concerned a provision of German law permitting employers to use fixed-term contracts when employing workers over the age of

89 Supra note 78, at Rec. $12 . \quad 90$ Ibid., Rec. 30.

91 Case C-249/96, Grantv South-West Trains [1998] ECR I-621.

92 Ibid., Rec. 45. See further, C. Favilli, La Non-Discriminazione nell'Unione Europea (2008), at 196-198.

93 Defrenne (III), supra note 78, at Rec. 29. See further, E. Ellis, EU Anti-Discrimination Law (2005), at 337-341.

94 Case C-144/04, Mangold v Helm [2005] ECR I-9981. 
52 without the normal requirement of objective justification for using temporary rather than indefinite contracts. The Court deemed this to be contrary to the Employment Equality Directive because it was direct discrimination on grounds of age that was not objectively justified. ${ }^{95}$ The application of the Directive to the facts of the dispute was, however, legally complicated. On the one hand, the litigation was between two private parties and the Court has consistently affirmed that directives cannot give rise to horizontal direct effect; that is, their provisions cannot be directly enforced in national courts against a private party. On the other hand, the facts arose during the extended period granted to Germany for transposition of the age provisions of the Employment Equality Directive, so recourse to the doctrine of direct effect was also obstructed by the non-expiry of the time limit for implementation. Ultimately, the Court circumvented both of these obstacles by turning to its case law on general principles of law. ${ }^{96}$

The Court's starting point concerned the place of the Employment Equality Directive in the hierarchy of legal sources:

Directive 2000/78 does not itself lay down the principle of equal treatment in the field of employment and occupation... the source of the actual principle underlying the prohibition of those forms of discrimination being found, as is clear from the third and fourth recitals in the preamble of the Directive, in various international instruments and in the constitutional traditions common to the Member States. ${ }^{97}$

This illustrates the importance of references to international human rights treaties within the Directive's preamble; the Court takes seriously these indicators of the Directive's rationale and its constitutional significance. This apparently emboldens it to ensure a high standard of protection of such rights:

Consequently, observance of the general principle of equal treatment, in particular in respect of age, cannot as such be conditional upon the expiry of the period allowed for the Member States for the transposition of a Directive intended to lay down a general framework for combating discrimination on grounds of age, in particular so far as the organization of appropriate legal remedies, the burden of proof, protection from victimization, social dialogue, affirmative action and other specific measures to implement such a Directive are concerned. ${ }^{98}$

The tenor of the decision in Mangold implies that the general principle of equality, as regards age, is the legal underpinning of the prohibition of age discrimination within employment. Moreover, the contents of the general principle are not limited to the prohibition of discrimination, but they extend to include a requirement to take measures for the enforcement of the principle, such as protection from victimization. This picture relegates the Directive to a residual role whereby it makes visible obligations that were already inherent within the general principle. Nevertheless, the Court did not go so far as to advocate an entirely autonomous application of the general principle to any employment contract. The contested German legislation regarding the use of fixed-term contracts stemmed from Germany's implementation of the Directive on Fixed-Term Work. ${ }^{99}$ Therefore, the Court was able to maintain its established orthodoxy that respect

95 Ibid., Rec. 65.

96 In relation to the non-expiry of the time limit for implementing the Directive, the Court indicated that this was qualified by the duty on states not to adopt measures incompatible with the aims of the Directive during the transposition period (Ibid., Rec. 72).

97 Ibid., Rec. $74 . \quad 98$ Ibid., Rec. 76.

99 Council Directive 1999/70, OJ 1999 L 175/43, concerning the Framework Agreement on fixed-term work concluded by ETUC, UNICE and CEEP. For the legislative history of the German rule, see Recs 16-19, Mangold, supra note 94. 
for the general principles of EC law was required when member states were implementing EC legislation. ${ }^{100}$ Consequently, the national court should set aside any provision of national law that was in conflict with those principles.

The decision in Mangold stimulated a strong and often critical debate amongst academics and Advocates General. ${ }^{101}$ In the context of this chapter, the key issue is what Mangold revealed about the constitutionalization of employment law. Without doubt, the Court recognizes that there are norms of higher legal status embedded within the Employment Equality Directive. Furthermore, by suggesting that the full panoply of enforcement measures found within the Directive are also expressions of the general principle of equality, the Court inclines towards the view that the entire Directive bears a constitutional significance. The Court apparently sees no objection to applying constitutional principles in the context of a private employment contract; indeed, it goes out of its way to ensure that non-discrimination on grounds of age can be secured by national courts even where the absence of horizontal direct effect of Directives presented a major stumbling block to achieving this end. Another striking feature of the decision, but one often overlooked, is the implicit hierarchy that the Court establishes between its treatment of the Fixed-Term Work Directive and the Employment Equality Directive. In contrast to its rich discourse surrounding the interpretation of the Employment Equality Directive, the Court's examination of the Fixed-Term Work Directive is relatively perfunctory and there is no evidence that the Court viewed this as engaging any fundamental social rights. This dichotomy reveals an apparent distinction between constitutionalized legislation, such as the Employment Equality Directive, and other elements of EU employment law that might be described as 'ordinary' legislation.

\section{The Expanding Role of General Principles within Equality Law}

The decision in Mangold raised questions about the ultimate destination of the Court's case law and whether it would eventually allow the general principle of equality to be directly applicable in a manner equivalent to Treaty provisions. ${ }^{102}$ The Court pulled back from any such trajectory in Bartsch. ${ }^{103}$ This was another case of age discrimination between private parties that arose before the deadline for implementation of the Employment Equality Directive. ${ }^{104}$ Unlike in Mangold, there was no immediate connection to any other element of EC law; it could not be argued that compliance with the general principle of equality was required because the member state was implementing EC legislation. In a very short judgment, the Court dismisses the case because there was 'no link with Community law'. ${ }^{105}$

100 Ibid., Rec. 75 .

101 For an overview, see Opinion of Advocate General Sharpston, Case C-427/06, Bartsch v Bosch und Siemens Hausgeräte Altersfürsorge GmbH [2008] ECR I-7245, paras 31-41.

102 McCrudden and Kountouris, 'Human Rights and European Equality Law', in H. Meenan (ed), Equality Law in an Enlarged European Union-Understanding the Article 13 Directives (2007) 73, at 90.

103 Bartsch, supra note 101.

104 The case concerned company pension scheme guidelines that limited access to a survivor's pension benefit to surviving spouses who were less than 15 years younger than the deceased. Mrs Bartsch was 21 years younger than her late husband and she was refused the survivor's pension as a result.

105 Ibid., Rec. 25. The brevity of the judgment contrasts with the rich analysis of Advocate-General Sharpston of the debate post-Mangold and her conclusion that general principles of law should not be given an autonomous application. 
Two years later, however, the Court reignited the issue through its judgment in Kücükdeveci. ${ }^{106}$ As in Mangold, the case revolved around a provision of German legislation that the Court deemed to be unlawful age discrimination. ${ }^{107}$ The deadline for implementation of the Employment Equality Directive had now passed, but the case was between an employee and a private employer, and the Court reiterated that Directives cannot give rise to horizontal direct effect. ${ }^{108}$ This led the Court into the same territory as that explored in Mangold; could general principles be a route for the enforcement of equal treatment rights within private employment relationships in a situation where a Directive could not be directly relied upon?

Advocate General Bot proposed a novel solution. He called upon the Court to recognise that certain directives are designed 'to facilitate the implementation of the general principle of equal treatment and non-discrimination' and the special status of these instruments should constitute an exception to the general restriction on the horizontal direct effect of directives. ${ }^{109}$ This approach seems to epitomise the idea of constitutionalization; certain legal instruments would be granted an elevated legal status based on their connection to the protection of fundamental rights. The Court forged a different path, but one that produced a similar end result. Before considering the Directive's provisions, the Court identifies its point of departure as being two key legal sources: the general principle of equality in EU law and the right to non-discrimination found within Article 21(1) of the EU Charter of Fundamental Rights. ${ }^{10}$ Even more clearly than in Mangold, the Directive is relegated to a secondary role, being a conduit for the application of the general principle:

It follows that it is the general principle of European Union law prohibiting all discrimination on grounds of age, as given expression in Directive 2000/78, which must be the basis of the examination of whether European Union law precludes national legislation such as that at issue in the main proceedings. ${ }^{111}$

In an interpretative leap, the Court concludes that the 'full effectiveness' of the general principle requires the national court to disapply any conflicting national legislation 'falling within the scope of European Union law'. ${ }^{112}$ Although a subtle change in wording, the Court's previous case law held that member states primarily had to comply with general principles when implementing EU law. ${ }^{113}$ In Kücükdeveci, the Civil Code provisions on length of notice entitlements dated from $1926,{ }^{114}$ so it would be a stretch of the legal imagination to describe these as 'implementing' EU law. Under the Court's new formulation, the general principle of equality is directly applicable in respect of any national measure than falls within the material scope of the Employment Equality Directive. In other words, any national legislation that relates to employment, access to self-employment, vocational training, or organizations of workers, employers, and

106 Case C-555/07, Kücükdeveci v Swedex GmbH \& Co KG, judgment of 19 January 2010, not yet published.

107 Ibid., Rec. 43. The period of notice to which an employee was entitled under the Civil Code accumulated according to the duration of the employment relationship; however, periods of employment prior to the age of 25 were not counted at all in calculating the employee's length of service.

108 Ibid., Rec. 46. $\quad 109$ Opinion of 7 July 2009, para. 70. $\quad 110$ Recs 21-22.

111 Rec. 27.

113 'Editorial Comments: The scope of application of the general principles of Union law: an ever expanding Union?', 47 CMLRev (2010) 1589, at 1590; Opinion of AG Sharpston, supra note 101, para. 69.

114 Opinion of AG Bot, supra note 106, para. 38. 
professionals ${ }^{115}$ is potentially subject to the general principle of equality. In terms of legal effects, this is rather close to permitting horizontal direct effect of equality Directives. ${ }^{116}$

Notwithstanding the innovative approach in Kücükdeveci, the Court continues to refrain from endorsing a fully autonomous application of the general principle of equality. This was exemplified in Römer, ${ }^{117}$ which concerned access to a supplementary retirement pension for a man in a registered same-sex partnership in circumstances where the benefit was restricted to those who were married. Concretely, this led to a reduction in the monthly pension for Mr Römer of around $€ 300$. The Court concluded that the denial of access to this benefit constituted direct discrimination on grounds of sexual orientation if the national court viewed same-sex couples as being in a comparable situation to married couples for the purposes of that benefit. ${ }^{18}$ Assuming that it was unlawful discrimination, the question arose of retrospective entitlement to the supplementary pension. Advocate General Jäskinen emphasized the role to be played by the general principle of equality irrespective of sexual orientation, taking into account the ECHR and the EU Charter of Fundamental Rights. ${ }^{119}$ Citing Mangold and Kücükdeveci, he argued that the Employment Equality Directive was merely an expression of a pre-existing principle of equality and the entitlement to retrospective payment of the retirement benefit should not be restricted to the date of entry into force of the Directive on 3 December 2003. ${ }^{120}$ Instead, he concluded that Mr Römer should have been entitled to the benefit from the date that he formed his registered partnership (15 October 2001).

In contrast, the Court returns to the more cautious terrain of its decision in Bartsch. It held that the national legislation on access to the supplementary pension only entered into the scope of EU law once the deadline for implementation of the Employment Equality Directive had passed; the general principle of equality irrespective of sexual orientation could not give rise to a free-standing right to equal treatment prior to this point in time. ${ }^{121}$

\section{Constitutionalization and EU Equality law: Unfinished Business?}

EU equality legislation provides a vivid illustration of the process of constitutionalization in action. Initially, gender equality provisions lacked any special legal significance; they were simply part of a range of 'ordinary' instruments designed to improve the functioning of the common market. The gradual reinterpretation of the role of equality legislation by courts and the legislature has led to a position where this area of law is now recognized for its close connection to the protection of fundamental rights.

115 Art. 3, Directive 2000/78, supra note 84.

116 Thüsing and Horler, 'Case comment: Case C-555/07 Kücükdeveci v Swedex Gmbh \& Co KG, judgment of the Court (Grand Chamber) of 19 January 2010, not yet reported', 47 CMLRev (2010) 1161 , at 1170 . In Kücükdeveci, the Court requires national courts to disapply national legislation where this is in conflict with the general principle of equality. This leaves open the question whether, in the absence of any national implementing legislation, the general principle could be directly applied as a source of rights. If this were true, then there would be no distinction between this and the doctrine of direct effect, but it remains unclear if the Court intends to go this far: see further, Opinion of AG Bot, supra note 106, para. 63.

117 Case C-147/08, Römer v Freie und Hansestadt Hamburg, judgment of 10 May 2011, not yet published.

118 Ibid., Rec. 52. The Court provides a strong indication in its reasoning that the national court should regard these situations as comparable (Recs 42-51).

119 Opinion of 15 July 2010, para. $147 . \quad 120$ Ibid., para. 146.

121 Römer, note 117, at Recs 60 and 63. 
The acknowledgement that equality legislation engages rights of constitutional significance impacts on the way in which the Court exercises its scrutiny. On some occasions, the Court clearly deploys the fundamental rights dimension to equality legislation in order to justify bold and imaginative interpretations of its scope. This has been particularly evident in recent case law where the Court has sought to ensure that employees can enforce EU equality rights against private employers even in situations where, according to the normal principles of EU law, this would not be possible.

It would be misleading, however, to exaggerate the impact of constitutionalization. While the discussion above has concentrated on high profile examples where the role of fundamental rights in the interpretation of the legislation is rendered visible, most equality cases continue to be resolved through a straightforward interpretation of the legislation without the Court needing to invoke constitutional principles. Cases like Mangold and Kücükdeveci have to be read alongside other cases on age discrimination where the Court is more cautious and conventional in its legal reasoning. ${ }^{122}$ It is often unclear why in one case the Court embarks upon an ambitious and innovative pathway drawing upon the general principle of equality while in other cases this aspect remains completely absent.

Looking to the future, an unresolved matter is the impact of the Charter of Fundamental Rights and its relationship to the unwritten general principles of law. ${ }^{123}$ Article 6 TEU provides a new Treaty foundation for both the Charter and the general principle of respect for fundamental rights. Kücükdeveci is a firm indication that the Court does not (currently) intend to replace its case law on the general principle of equality with a primary emphasis on the equality articles in the Charter. Instead, it blends these instruments together, citing both as authority for applying the principle of equality in respect of age discrimination. In this respect, it seems that the new legal status of the Charter reinforces an existing trajectory towards constitutionalization and it may help to explain the Court's willingness to push the boundaries of equality law within Kücükdeveci. Similar signals can be gleaned from the Court's decision in Test-Achats. ${ }^{124}$ In this case, the Court took the unusual step of striking down an exception to the prohibition of discrimination that was expressly included within secondary legislation. Specifically, the 2004 Directive on gender equality in goods and services permitted member states, under certain conditions, to allow proportionate differences in premiums and benefits within insurance and financial services based on sex. ${ }^{125}$ The Court held that the indefinite nature of this exception was not compatible with Articles 21 and 23 of the Charter and that it would be invalid with effect from 21 December 2012. ${ }^{126}$ As with Mangold and Kücükdeveci, this decision reinforces a tendency to focus on the primacy of constitutional sources, whether the general principle of equality or the Charter, and to place less weight on secondary legislation. Again, the Court shows

122 E.g. Case C-388/07, R (the Incorporated Trustees of the National Council for Ageing (Age Concern England)) $v$ Secretary of State for Business, Enterprise and Regulatory Reform [2009] ECR I-1569; Case C-45/09, Rosenbladt v Oellerking Gebäudereinigungsges. $m b H$, judgment of 12 October 2010, not yet published; Joined Cases C-159/10 and C-160/10, Fuchs and Köhler v Land Hessen, judgment of 21 July 2011, not yet published.

123 Peers, 'The EU Charter of Rights and the Right to Equality', 11 ERA Forum (2011) 571, at 583.

124 Case C-236/09, Test-Achats, supra note 15.

125 Art. 5(2), Council Directive 2004/113, OJ 2004 L 373/37, implementing the principle of equal treatment between men and women in the access to and supply of goods and services.

126 Test-Achats, supra note 124, Rec. 32. This was the date specified within the Directive when member states were required to review the need for this exception, but individual states would have been free to decide to continue to permit such differences in treatment. 
no reluctance to apply the full vigour of constitutional equality principles into private contractual relationships.

Test-Achats may also reopen the debate on the direct applicability of the general principle of equality. While the Court has limited this to the scope of Directives where the deadline for implementation has passed (as in Bartsch and Römer), the decision in Test-Achats reveals that limitations housed within the Directives may be vulnerable to challenge as inconsistent with the Charter's equality guarantees. Once a broad sector of activity has been subject to legislative regulation, such as employment or services, then the Charter rights to equality appear to be directly applicable notwithstanding any attempts to curtail this within the legislation. ${ }^{127}$ Restrictions in existing equality legislation such as the exclusion of protection from disability and age discrimination within the armed forces, ${ }^{128}$ or the possibility to maintain different ages for men and women in access to retirement pensions, ${ }^{129}$ could now be subject to judicial review for compatibility with the equality provisions found within the Charter of Fundamental Rights. Nevertheless, it seems unlikely that the Court will take the radical step of embracing a full and unrestrained direct applicability for the general principle of equality. Likewise, it would be unrealistic to expect that the Court will rely regularly on the Charter to unpick the careful political compromises reflected in equality legislation. Decisions such as Mangold or Test-Achats provoke genuine controversy over the Court's respect for the limits to EU competences and established legal doctrines (such as direct effect). In so far as any pattern is emerging, the Court seems willing on occasions to invoke the Charter and/or the general principle of equality to enhance the effectiveness of EU equality legislation. The Court is undoubtedly cognizant of the polemical debate that surrounds such cases and this may account for its reluctance to engage more frequently with constitutional equality principles.

\section{Searching the Outer Limits of Constitutionalization: The Personal Scope of Employment Rights}

\section{A. Introduction}

The previous section considered an area of employment law where there is explicit evidence of constitutionalization and where there is a wide consensus that the law engages fundamental human rights; the principle of equal treatment and/or the right to non-discrimination are found in most national constitutions as well as many international and European human rights instruments. In order to provide contrast, this section examines a branch of employment law where it is more difficult to identify an overt connection to internationally recognized fundamental rights. In addition, this case study deals with an issue where the role for the EU is partial and contested, unlike the solid corpus of EU equality legislation.

In any system of employment law, it seems inevitable that there is a gateway question regarding who is entitled to benefit from the rights conferred. If, for example, the law establishes a minimum entitlement to paid annual holidays, then we need to know who enjoys this right. The traditional outlook has been to draw a binary distinction between employed persons and self-employed persons; the former falling inside the

127 Ibid., Recs 20-21. 128 Art. 3(4), Directive 2000/78, supra note 84.

129 Art. 7(1)(a), Council Directive 79/7, OJ 1979 L 6/24, on the progressive implementation of the principle of equal treatment for men and women in matters of social security. 
circle of beneficiaries of employment law and the latter falling outside. This simplistic dichotomy has been subject to academic critique for failing to reflect the complexity of the modern labour market. ${ }^{130}$ The decline in the standard employment relationship has spawned a rich array of different contractual arrangements for the performance of work. For example, the direct relationship between employer and worker is sometimes replaced by the insertion of third parties, such as temporary work agencies. Leighton and Wynn draw attention to the emergence of 'quadrilateral' employment relationships where individuals work through personal service companies who in turn are provided to an employer via an agency. ${ }^{131}$ Moreover, the classic image of the self-employed person as an entrepreneur running her own business does not capture the diversity of situations that fall under this label. For instance, many individuals working in the construction industry are hired on a casual basis under a contract to provide services. This leads to a position where, in the United Kingdom, one-third of construction workers are estimated to be self-employed, ${ }^{132}$ yet many would not resemble the typical image of an independent business. Some European legal systems have resorted to the creation of intermediate categorizations such as 'economically dependent autonomous workers' or 'para-subordinate' workers to address these social realities. ${ }^{133}$

From a private law perspective, the proliferation of working arrangements might be viewed as the ultimate expression of freedom of contract; individuals and firms are able to order their relations according to their preferences. Some individuals value the autonomy and flexibility of working (for example) as freelance consultants without the obligations inherent in a contract of employment. ${ }^{134}$ Yet the inequality of bargaining power means that 'choice' is a mirage for many. It is reasonable to doubt whether, say, migrant agricultural workers recruited via transnational agencies have any significant bargaining power to shape the nature of their contractual relations. ${ }^{135}$ In response, courts and legislators sometimes broaden the personal scope of employment rights in order to counter the risk of individuals being deprived of such rights through firms avoiding the contract of employment.

In relation to EU law, a complex picture emerges. There is no overarching status of 'worker' that applies in a uniform manner across all EU employment legislation. Instead, each individual piece of legislation has adopted its own stance on the personal scope of application. This variability has to be combined with the subsequent interpretative gloss from the Court of Justice. In relation to some employment rights, it applies a harmonized European definition of 'worker', while in other cases it leaves this as a matter for national discretion (subject to reasonable limits). The question explored by this section of the chapter is whether constitutionalization exerts an influence on determining the personal scope of employment rights. It begins by considering what, if any, fundamental rights are engaged in this area of law, followed by a review of three discrete areas of EU employment law.

130 M. Freedland and N. Kountouris, The Legal Construction of Personal Work Relations (2011), at 104; Fredman, 'Women at Work: The Broken Promise of Flexicurity', 33 ILJ (2004) 299, at 307.

131 Leighton and Wynn, 'Classifying Employment Relationships-More Sliding Doors or a Better Regulatory Framework?', 40 ILJ (2011) 5, at 28.

132 D. Walters et al., 'The Role and Effectiveness of Safety Representatives in Influencing Workplace Health and Safety', Health and Safety Executive Research Report 363 (2005), at 81.

133 Freedland and Kountouris, supra note 130, at 115.

134 P. Leighton et al., Out of the Shadows-Managing Self-Employed, Agency and Outsourced Workers (2007), at 9 .

135 E.g. Consistent Group Ltd v Kalwak [2008] IRLR 505 (Court of Appeal). 


\section{B. Is There a 'Right' to be a Worker?}

The first question that arises is whether there is any basis for treating the personal scope of employment rights as an issue of constitutional significance. Reformulated, we could ask whether there is any fundamental right to be treated as a 'worker'? Although recognition as a worker is often the doorway into employment rights, most international human rights instruments are silent as to its meaning. The Universal Declaration of Human Rights simply states that 'everyone who works has the right to just and favourable remuneration', ${ }^{136}$ while 'everyone has the right to rest and leisure, including reasonable limitation of working hours and periodic holidays with pay'. ${ }^{137}$ Part I of the European Social Charter (both in the 1961 version and in the 1996 revision) refers either to 'everyone' or 'all workers'. The Appendix to the Revised European Social Charter sheds some light on the intended meaning of this term by virtue of permitted exemptions. In relation to Article 24 on 'protection in cases of termination of employment', the Appendix clarifies that states may exclude fixed-term contract workers or 'workers engaged on a casual basis for a short period'. The logical implication of these exceptions is that, save where permitted, the Charter's personal scope extends to casual and/or temporary work.

The approach taken by the European Social Charter can be traced to that found in the instruments of the International Labour Organization (ILO). ILO Conventions frequently apply to the broad category of 'worker', ${ }^{138}$ subject to specific exceptions. ${ }^{139}$ In the late 1990s, the ILO attempted to confront directly the borders to the concept of 'work' by drafting a Convention on 'contract labour'. This would have extended core employment rights to:

workers in 'triangular' relationships, as well as workers who perform work or provide services to other persons within the legal framework of a civil or commercial contract, but who in fact are dependent on or integrated into the firm for which they perform the work or provide the service in question. ${ }^{140}$

Nevertheless, agreement could not be reached and the planned Convention was not adopted. ${ }^{141}$ Instead, the ILO returned to the issue via the softer mechanism of Recommendation 198 concerning the Employment Relationship. ${ }^{142}$ This sought to balance the reality that 'situations exist where contractual arrangements can have the effect of depriving workers of the protection they are due', ${ }^{143}$ while at the same time endorsing the position that worker protection 'should not interfere with true civil and commercial relationships'. ${ }^{144}$ The Recommendation focuses on clarifying the criteria in national law and policy for identifying genuine employment relationships, as well as exhorting states to take steps to combat disguised employment.

136 Art. 23(3). Similarly, the International Covenant on Economic, Social and Cultural Rights refers to 'the right of everyone to the enjoyment of just and favourable conditions of work' (Art. 7).

137 Art. 24.

138 E.g. the preamble to Convention 189 concerning Decent Work for Domestic Workers (16 June 2011) states 'international labour Conventions and Recommendations apply to all workers, including domestic workers, unless otherwise provided'.

139 E.g. Convention 158 on Termination of Employment (1982) includes the same restrictions as those found in the Appendix of the Revised European Social Charter.

140 International Labour Conference, 'The Scope of the Employment Relationship', Report V, 91st Session, 2003, at 6 .

141 See further, N. Countouris, The Changing Law of the Employment Relationship-Comparative Analyses in the European Context (2007), at 161.

142 Adopted 15 June 2006. $\quad 143$ Preamble. 144 Para. 8. 
Against this backdrop, it is unsurprising to discover that the EU Charter of Fundamental Rights is also framed by open-textured references to 'every worker' ${ }^{145}$ and the meaning of this term is not further elucidated within the Explanations attached to the Charter. The general tenor of international instruments suggests a common intention to ensure broad coverage of different types of workers, but this is something short of a specific 'right' to be treated as a worker. As the failed ILO Convention on Contract Labour revealed, there is limited international consensus on the application of fundamental employment rights to persons working on the hazy boundary between employment relationships and commercial relationships. Given the ambiguity surrounding the regulation of this issue, it might be concluded that this is one area of employment law where constitutionalization is unlikely to have an impact. Unlike equality law, it is hard to make the case that ensuring the protection of (for example) quasi self-employed persons is a matter of constitutional significance. This might seem to be a good example of an issue that is left to the regulation of 'ordinary' employment law and the balancing of competing economic and social interests. Even here, though, evidence arises to suggest that constitutionalization does have an impact, albeit more indirect and subtle than in relation to equality law.

The potential impact of constitutionalization is exposed in situations where the Court of Justice is confronted with the need to determine whether a particular individual is entitled to be treated as a worker. The Court could resolve such interpretative questions without any recourse to constitutional principles or fundamental rights. It could, for instance, leave this to be resolved by national courts in accordance with national definitions of the employment relationship, or it could apply conventional techniques of legislative interpretation. What emerges, however, is evidence that the Court's approach to the personal scope of employment rights is shaped by an analysis of whether the rights at stake are fundamental within the EU legal order. This pathway for the Court was evident from its early engagement with this topic. A cornerstone of the common market was the free movement of workers and inevitably this posed the question of who was a 'worker'? As is well documented, the Court decided that a harmonized concept of 'worker' should be applied in order to ensure consistency across the member states. ${ }^{146}$ To this end, it adopted the following formula: 'the essential feature of an employment relationship, however, is that for a certain period of time a person performs services for and under the direction of another person in return for which he receives remuneration'. ${ }^{147}$ In the context of this chapter, it is telling to note the justification that the Court provides for adopting a relatively broad understanding of the status of worker: 'these concepts define the field of application of one of the fundamental freedoms guaranteed by the Treaty and, as such, may not be interpreted restrictively'. ${ }^{148}$ The constitutional significance of free movement of workers becomes crucial in the Court's approach to determining the personal scope of this right.

The remainder of this section explores whether there is evidence that the Court extends this approach across employment rights. Is its outlook on the personal scope of employment rights determined by whether the right in question is deemed to be one of constitutional significance? To that end, three examples are considered: equality law; the Working Time Directive; and the Acquired Rights Directive.

\footnotetext{
145 E.g. Arts 30 and 31.

146 Case 53/81, Levin v Staatssecretaris van Justitie [1982] ECR 1035, Rec. 11.

147 Case 66/85, Lawrie-Blum v Land Baden-Württemberg, [1986] ECR 2121, Rec. 17.

148 Levin, supra note 146, Rec. 13.
} 


\section{Equality Law}

The personal scope of EU equality law has been explored in a significant number of cases involving various directives and treaty provisions. This section does not attempt to provide a comprehensive analysis of this rich body of law, ${ }^{149}$ but it considers several examples from EU gender equality law to illustrate the role that constitutionalization plays in the Court's approach to this issue. The case of Allonby ${ }^{150}$ is particularly illuminating. Ms Allonby had been working for six years as a part-time lecturer employed on a succession of one-year contracts and paid on an hourly basis. For financial reasons, the college decided to cease direct employment of part-time lecturers and instead to recruit them via a temporary employment agency. Ms Allonby was dismissed, but then continued to work for the college via the agency. This had the effect, however, of reducing her salary and depriving her of certain employment benefits, including exclusion from the occupational pension scheme for teachers. The exclusion from the pension scheme was challenged as a potential breach of the right to equal pay for women and men in former Article $141 \mathrm{EC}^{151}$ due to the significantly higher number of female teachers affected by this reorganization of employment relationships. ${ }^{152}$

The preliminary stumbling block for Ms Allonby's claim was whether she fell into the category of 'worker' for the purposes of the right to equal pay. The temporary work agency emphasized that it applied a condition that all lecturers registering with the agency did so as self-employed persons. ${ }^{153}$ There was no definition of 'worker' in Article 141 EC and the Court accepted that it was not intended to 'include independent providers of services who are not in a relationship of subordination with the person who receives the services'. ${ }^{154}$ Nevertheless, the Court rejected the idea that the nature of the relationship could be determined according to national legal definitions of employment/ self-employment, especially if the individual's independence was 'merely notional'. ${ }^{155}$ Instead, it reiterated the broad definition of worker previously crafted in free movement law. In so doing, the Court chose to constrain both national autonomy and party autonomy; even though the contractual arrangements had been designed to reflect the domestic legal approach to self-employment, these were supplanted by the Court's conception of what it means to be a worker. Tellingly, the Court justifies this approach by reference to constitutional principles. It described the Treaty right to equal pay as 'a specific expression of the principle of equality for men and women, which forms part of the fundamental principles protected by the Community legal order'. ${ }^{156}$ Advocate General Geelhoed also drew attention to the right to gender equality in the Charter of Fundamental Rights and viewed this as essential protection for workers 'whether employed or self-employed'. ${ }^{157}$

The breadth of the personal scope of EU gender equality law is reinforced by the decision in Danosa. ${ }^{158}$ Ms Danosa was appointed to be the sole member of a Board of Directors for a limited liability company. Seven months later, the general meeting of the shareholders of the company decided to remove her from this position. At the time, she

149 For more extensive analysis, see Countouris, supra note 141, at 179-185.

150 Case C-256/01, Allonby v Accrington \& Rossendale College [2004] ECR I-873.

151 Now Art. 157 TFEU.

152 Of those made redundant and then re-employed via the agency, 231 were women and 110 were men. Of those retained as directly employed lecturers by the College, the majority were men (Opinion of AG Geelhoed, 2 April 2003, para. 11).

153 Opinion of Advocate General, para. 31. $\quad 154$ Rec. 68 of judgment. $\quad 155$ Rec. 71.

156 Rec. $65 . \quad 157$ Opinion of Advocate-General, para. 53.

158 Case C-232/09, Danosa v LKB Lizings SIA, supra note 11. 
was 11 weeks pregnant and she brought a case challenging her dismissal. The referring court raised the question of whether this was compatible with the EU Pregnant Workers Directive, which includes protection from dismissal during pregnancy. ${ }^{159} \mathrm{~A}$ key issue was whether an individual performing such a role fell within the personal scope of the Pregnant Workers Directive. The company and the Latvian government argued that this was not an employment relationship, but one based on civil law. In their view, applying the Directive to this situation would be 'an unwarranted interference in shareholders' rights'. ${ }^{160}$ Despite this appeal to commercial freedom, the Court felt that the core elements of its concept of worker were present: remuneration for services performed and the carrying out of services under direction or control. In relation to the latter, it accepted that as a sole Board member, Ms Danosa had 'a margin of discretion in performing her duties'. ${ }^{161}$ Yet the fact that the shareholders could dismiss her was taken, in itself, to provide evidence that she was working under the control of another body. ${ }^{162}$ This is a remarkably broad concept of being a 'worker' that reduces the requirement of subordination to a minimal level. Most commercial relationships are likely to involve the provision of services for remuneration and the capacity for the service recipient to terminate the relationship. Arguably the decision in Danosa reflects the logic of constitutionalization; the Court's primary concern becomes the protection of the individual from a breach of fundamental rights and it downgrades the importance of the legal classification of her relationship. Faced with arguments over whether her situation fell into the scope of the Pregnant Workers Directive, the Equal Treatment Directive, ${ }^{163}$ or a Directive on the Equal Treatment of Self-Employed Persons, ${ }^{164}$ the Court simply declares:

[W] hichever Directive applies, it is important to ensure, for the person concerned, the protection granted under EU law to pregnant women in cases where the legal relationship linking her to another person has been severed on account of her pregnancy. ${ }^{165}$

This line of reasoning seems to detach equality rights from the confines of the employment relationship and reflects the universalistic tendency of human rights law. The latter is typically founded on the protection of all persons simply by virtue of their human personhood. In so far as equality rights may be submerged into the general corpus of human rights law, then there is potential to side-step tricky issues around the legal categorization of the employment relationship. This approach is, however, unlikely to be applicable to other employment rights where the connection to human rights law is more tenuous.

\section{The Working Time Directive}

Given the analysis earlier in this chapter of the extent of constitutionalization of equality law, it is perhaps unsurprising to find that this also permeates issues around its personal scope. It is, therefore, necessary to examine other areas of EU employment law to identify whether constitutionalization has a wider impact. The second example to

159 Art. 10, Council Directive 92/85, OJ 1992 L 348/1, on the introduction of measures to encourage improvements in the safety and health at work of pregnant workers and workers who have recently given birth or are breastfeeding.

160 Opinion of AG Bot, 2 September 2010, para. $98 . \quad 161$ Rec. 49 of judgment.

162 Rec. 51.163 Council Directive 76/207, OJ 1976 L 39/40.

164 Council Directive 86/613, OJ 1986 L 359/56.

165 Rec. 70. The Court cites Art. 23 EUCFR on equality for women and men in support of its decision. 
be considered is the Working Time Directive. ${ }^{166}$ The Directive regulates entitlement to breaks from work, such as daily and weekly rest periods, as well as maximum weekly working time and the right to paid annual leave. Many of its provisions are phrased in broad terms: 'every worker is entitled to paid annual leave of at least four weeks'. ${ }^{167}$ The Directive does not contain any definition of 'worker', but its scope is based upon corresponding provisions in the EU Framework Directive on Health and Safety. ${ }^{168}$ The latter instrument does contain a definition of worker, but this does not shed much light on its intended meaning: 'worker: any person employed by an employer'. ${ }^{169}$

As mentioned in section 3 of this chapter, the BECTU case $^{170}$ provided the first illustration of the Court's approach to the personal scope of 'worker' in the context of the Working Time Directive. When implementing the Directive, the UK had excluded from the entitlement to paid annual leave those employed under contracts with a duration of less than 13 continuous weeks. The Court found this to be incompatible with the Directive, noting that it did not draw any distinction between those working under indefinite duration or fixed-term contracts. ${ }^{171}$ Significantly, it grounded its reading of the Directive in a rights-based analysis. Citing the 1989 EC Social Charter, it concluded that paid annual leave was 'a social right directly conferred by that Directive on every worker'. ${ }^{172}$ This was reinforced in the accompanying Opinion of Advocate General Tizzano. He cited the Universal Declaration of Human Rights, the 1961 European Social Charter, the International Covenant on Economic, Social and Cultural Rights, and the 2000 EU Charter of Fundamental Rights to support the conclusion that paid annual leave constituted a 'fundamental social right'. ${ }^{173}$

Subsequent case law continues to frame the Working Time Directive as engaging the protection of particularly important social rights, which then leads the Court to favour a broad interpretation of its personal scope. ${ }^{174}$ For example, in Union syndicale Solidaires Isère $v$ Premier ministre and others, ${ }^{175}$ the issue at stake was the entitlement to daily rest breaks for those working on a casual and seasonal basis in holiday and leisure centres for children during school vacations. French national legislation classified these relationships as falling under the remit of 'educational commitment' and outside the scope of the Labour Code. Such work was limited to an annual maximum of 80 days, but there was no entitlement to a daily rest period of 11 consecutive hours (as required by the Directive). The Court characterizes the provisions on rest periods as 'rules of European Union social law of particular importance from which every worker must benefit'. ${ }^{176}$ The Directive had to be read broadly and the national classification of the relationship had no consequence for determining whether the individual met the EU law definition of 'worker'. ${ }^{177}$ Accordingly, educational commitments were deemed to fall within the scope of the Directive and such individuals were, in principle, entitled to daily rest periods.

166 Council Directive 2003/88, supra note 62.

167 Ibid., Art. 7.

168 Ibid., Art. 1(3).

169 Art. 3(a), Council Directive 89/391, OJ 1989 L 183/1, on the introduction of measures to encourage improvements in the safety and health of workers at work. Art. 3(b) defines employer as 'any natural or legal person who has an employment relationship with the worker and has responsibility for the undertaking and/or establishment'.

170 BECTU, supra note 61. 171 Ibid., Rec. $46 . \quad 172$ Ibid., Rec. 47.

173 Opinion of 8 February 2001, paras 22-28.

174 The Court now explicitly applies the definition of 'worker' found in free movement law when interpreting the personal scope of the Working Time Directive: Case C-337/10, Neidelv Stadt Frankfurt am Main, judgment of 3 May 2012, not yet published, Rec. 23.

175 Case C-428/09, judgment of 14 October 2010, not yet published. $\quad{ }^{176}$ Ibid., Rec. 36.

177 Ibid., Recs 22 and 30. 
A further illustration of the Court's tendency to give an expansive reading to the personal scope of the Working Time Directive arises in a bundle of decisions relating to the rights of workers during sick leave. Specifically, these cases pose the question of whether (and when) a worker on sick leave can take paid annual leave. The status of a worker on sick leave, especially long-term sick leave, is a matter that varies between national jurisdictions. ${ }^{178}$ Some obligations of the employment relationship are likely to be suspended after a certain point in time, notably the obligation to provide remuneration. When the Court of Justice was first asked to consider whether a worker on sick leave continued to enjoy the right to take paid annual leave during the actual period of sick leave, all eight member states who intervened in the case, and the European Commission, advised that this should not be possible. ${ }^{179}$ Nevertheless, the Court started its analysis by considering the status of the legal norm, noting that paid annual leave is 'a particularly important principle of Community social law from which there can be no derogations'. ${ }^{180}$ In relation to those off work for more than one year, the Court highlighted that ILO Convention 132 required this to be treated as part of the period of service. ${ }^{181}$ Accordingly, the Court rejected the idea that long-term sickness extinguished entitlement to paid annual leave. ${ }^{182}$ While the Court has referred to ILO Conventions in earlier judgments, ${ }^{183}$ its practice in doing so is rather infrequent and haphazard. In relation to the Working Time Directive, it has a stronger mandate for considering ILO instruments, because recital 9 in the Directive's preamble specifically calls for ILO principles to be taken into account. ${ }^{184}$ More recently, it has overtly linked this conclusion to Article 31(2) of the Charter of Fundamental Rights: 185 'every worker has the right to limitation of maximum working hours, to daily and weekly rest periods and to an annual period of paid leave'.

Admittedly, this is not an absolute right. The Court has accorded some flexibility for employers where sick leave is shorter than one year in duration. ${ }^{186}$ Conversely, it has imposed restrictions on the ability to accumulate paid annual leave entitlement. In Schulte, a worker who had been on long-term sick leave for three years did not have the right to accumulate paid annual leave for each of these years and the Court accepted the legitimacy of imposing temporal restrictions on carrying over leave from one working year to the next. ${ }^{187}$ In reaching this conclusion, it drew upon the restrictions authorized in ILO Convention 132.

Taking an overview, the example of the Working Time Directive appears to echo the approach found in equality law. The Court identifies that the underlying rights found within the legislation are of constitutional significance because of their connection to fundamental social rights. This conclusion has been consolidated following the acquisition of Treaty status by the Charter of Fundamental Rights, and the inclusion therein of Article 31(2). The

178 Freedland and Kountouris, supra note 130, at 214.

179 The interveners were Germany, the UK, the Czech Republic, Italy, the Netherlands, Poland, and Slovenia: Joined Cases C-350/06, Schultz-Hoffv Deutsche Rentenversicherung Bund and C-520/06, Stringer v Her Majesty's Revenue and Customs [2010] ECR I-179.

180 Ibid., Rec. 22.

181 Ibid., Rec. 38; Convention 132 concerning Annual Holidays with Pay (Revised).

182 See also Case C-282/10, Dominguez v Centre informatique du Centre Ouest Atlantique, Préfet de la region Centre, judgment of 24 January 2012, not yet published.

183 E.g. Defrenne III, supra note 78, at Rec. 28.

184 'Account should be taken of the principles of the International Labour Organisation with regard to the organization of working time, including those relating to night work', Council Directive 2003/88, supra note 62.

185 Case C-214/10, KHS AG v Schulte, judgment of 22 November 2011, not yet published, Rec. 37.

186 Schultz-Hoff, supra note 179, Recs 34-35. 187 Schulte, supra note 185, Rec. 33. 
treatment by the Court of those on sick leave poses slightly different issues to the employed/ self-employed distinction. Yet an analogy exists in so far as those on long-term sick leave are also in a precarious situation where the normal statutory and contractual entitlements of a worker may be denied. The Court relies on the fundamental nature of the rights found in the Directive to favour a very broad interpretation of its personal scope.

\section{E. The Acquired Rights Directive}

The final example considered in this section concerns an element of EU employment law where the connection to fundamental social rights is less evident, at least in comparison to equality and working time. The Acquired Rights Directive was originally adopted in 1977, but revised and consolidated in $2001 .{ }^{188}$ It seeks to protect employment rights in the event of 'a change in the natural or legal person who is responsible for carrying on the business and who incurs the obligations of an employer towards employees of the undertaking. ${ }^{189}$ Typical examples would be the acquisition of a business or, depending on the circumstances, a change following a competitive tendering process, such as the contracting out of cleaning services. ${ }^{190}$ In terms of personal scope, the Directive places the emphasis on resolving this by reference to national law. Article 2 states:

(1) (d) 'employee' shall mean any person who, in the Member State concerned, is protected as an employee under national employment law.

(2) This Directive shall be without prejudice to national law as regards the definition of contract of employment or employment relationship.

Unsurprisingly, the Court has been faced with questions surrounding the personal scope of the Directive. The flagship case in this area is Danmols Inventar. ${ }^{191} \mathrm{Mr}$ Mikkelsen was originally employed as a works foreman, but, following a transfer of the undertaking, he became a co-owner and chair of the Board of Directors, although he continued to perform the same work and received the same salary. The company subsequently became insolvent and Mr Mikkelsen brought legal proceedings to recover compensation for the termination of his employment and holiday pay. In order to rely upon the Directive, it needed to be determined if he fell within its personal scope, especially in the light of his partial ownership of the company. In that regard, Mr Mikkelsen argued that so long as the individual does not occupy a dominant position on the Board of Directors, then an employment relationship should be found to exist. The Court acknowledged that with regard to free movement law, it had developed a harmonized concept of worker; however, it rejected the application of that approach to the Acquired Rights Directive:

Directive no. $77 / 187$ is intended to achieve only partial harmonization essentially by extending protection guaranteed to workers independently by the laws of the individual Member States to cover the case where an undertaking is transferred... it is not however intended to establish a uniform level of protection throughout the Community on the basis of common criteria. ${ }^{192}$

188 Council Directive 2001/23, supra note 18.

189 Joined Cases C-173/96 and C-247/96, Sánchez Hidalgo and others v Asociación de Servicios Aser and Sociedad Cooperativa Minerva, Ziemannv Ziemann Sicherheit GmbH and Horst Bohn Sicherheitsdienst [1998] ECR I-8230, Rec. 23.

190 E.g. Case C-392/92, Schmidt, supra note 20.

191 Case 105/84, Foreningen af Arbejdsledere I Danmark v A/S Danmols Inventar [1985] ECR 2639. See also, Freedland and Kountouris, supra note 130, at 391.

192 Ibid., Rec. 26. 
In contrast to the approach found in equality or working time law, the Court exercised judicial self-restraint in relation to the personal scope of the Acquired Rights Directive, leaving this to the discretion of national law.

Subsequent decisions have largely conformed to this approach. ${ }^{193}$ In Collino and Chiappero, ${ }^{194}$ decided in 2000, the Court expressly confirmed that the approach taken in Danmols Inventar, decided in 1985, was still valid: 'contrary to the submissions of the Finnish government and the Commission, the Directive does not apply to persons who are not protected as employees under their national employment law, regardless of the nature of the tasks those persons perform'. ${ }^{195}$ The Court's approach can, at one level, be explained by the textual requirements of the Directive. Article 2, cited above, clearly indicates that the personal scope of the Directive is a matter for national law and this has been cited by the Court as support for its conclusion that the Directive only aims at a 'partial harmonisation' of national law. ${ }^{196}$ Nevertheless, the Court has not always felt itself strictly bound by similar language in other instruments.

Clause 2(1) of the Framework Agreement on Part-Time Work echoes the approach to personal scope found in the Acquired Rights Directive: 'this agreement applies to part-time workers who have an employment contract or employment relationship as defined by the law, collective agreement or practice in force in each Member State.${ }^{197}$ Initially, the Court took the view that questions relating to the personal scope of application of the Framework Agreement were matters for national courts to determine. ${ }^{198}$ More recently, however, the Court substantially qualified the discretion accorded to national law. In O'Brien, the case concerned the exclusion of some part-time judges in the United Kingdom from access to an occupational pension. ${ }^{199}$ According to national law, judges were deemed to be 'office-holders' rather than 'workers', and hence fell outside the scope of the legislation implementing the Framework Agreement on Part-Time Work. While acknowledging that clause 2(1) leaves it for national law to determine who constitutes a 'part-time worker', the Court said that 'certain words used in that Agreement may be defined in accordance with the national law and practices on condition that they respect the effectiveness of the Directive and the general principles of EU law'. ${ }^{200}$ This principle was amplified by Advocate General Kokott, who drew an express link between the Framework Agreement and the protection of fundamental rights:

The prohibition of discrimination laid down therein is simply a specific expression of the general principle of equality, which is one of the fundamental principles of EU law and is enshrined in arts 20 and 21 of the Charter of Fundamental Rights of the European Union. ${ }^{201}$

Having identified the connection between the Framework Agreement and the general principles of EU law, the Court proceeded to examine in some detail the nature of judges' employment relationship. While leaving the formal decision to the referring court, it provided a strong indication that judges could not be excluded from the personal scope

193 E.g. citation of Danmols Inventar in Sánchez Hidalgo, supra note 189, at Rec. 24. The Court has, though, clarified that it is sufficient to establish the existence of an employment 'relationship' under national law; a 'contractual link' is not required: Case C-242/09, Albron Catering BV v FNV Bondgenoten, Roest, judgment of 21 October 2010, not yet reported, Rec. 24.

194 Case C-343/98, Collino and Chiappero v Telecom Italia SpA [2000] ECR I-6659.

195 Ibid., Rec. 38.

197 Emphasis added; Council Directive 97/81, OJ 1998 L 14/9, concerning the Framework Agreement on part-time work concluded by UNICE, CEEP and the ETUC.

198 Case C-313/02, Wippel v Peek \& Cloppenburg GmbH \& Co. KG [2004] ECR I-9483, Rec. 40.

199 Case C-393/10, O'Brien v Ministry of Justice, judgment of 1 March 2012, not yet published.

200 Ibid., Rec. 34. 201 Footnotes omitted; Opinion of 17 November 2011, para. 41. 
of the Framework Agreement, notwithstanding clause 2(1) apparently leaving this to be resolved by national law.

The approach taken in O'Brien suggests that, where a connection to fundamental rights or general principles of law is identified, then the Court will intervene to ensure that the personal scope of application is interpreted widely, irrespective of whether the Directive provides for this to be determined by national law. ${ }^{202}$ This poses the question of why the Court remains more aloof when faced with disputes over the personal scope of the Acquired Rights Directive. One explanation may be that the Court has not identified any significant connection between the provisions of the Acquired Rights Directive and the protection of fundamental rights. Unlike equality or working time, there are no provisions of international instruments that are expressly addressed to the situation where there is a change in the identity of the employer. This is not, for example, explicitly included within the Council of Europe's Revised European Social Charter. ${ }^{203}$ Similarly, it is not dealt with directly in the EU Charter of Fundamental Rights. ${ }^{204}$ As discussed in section 2, the Acquired Rights Directive appears to be one element of EU employment law where rights have not been subject to constitutionalization.

\section{Conclusion}

The theme of this collection is the constitutionalization of European private law. While employment law finds its roots in private law, it has become distinct over time due to the extensiveness of social regulation of the employment relationship. Traditional concerns of private law, such as freedom of contract and protection of property rights have withered and feature rarely in discourse surrounding EU employment legislation. There is, of course, an enduring debate about the optimal balance between worker protection and flexibility for employers, but this is not often framed as an ideological dispute over the entitlement of the state to interfere in the private contract of employment. The acceptance that employment relationships will be subject to externally imposed social regulation may explain why this area of private law has been rather open to the tendency for constitutionalization. From a very early stage, the Court of Justice was willing to apply rights based on the provisions of the EEC Treaty directly into the contract of employment, ${ }^{205}$ with no apparent qualms about the implicit infringement of freedom of contract. While the original Treaties had relatively few provisions of immediate relevance to employment relations, the subsequent emergence of the 1989 EC Social Charter and, most especially, the 2000 Charter of Fundamental Rights has cemented the notion that some elements of employment law engage fundamental rights of constitutional significance.

\footnotetext{
202 The Court will face a similar issue in a pending reference from the French Cour de Cassation. The dispute concerns the exclusion of those working under certain types of contract from the thresholds triggering rights to information and consultation under Directive 2002/14, OJ $2002 \mathrm{~L} \mathrm{80/29.} \mathrm{While} \mathrm{the}$ Directive defines 'employee' according to national employment law (Art. 2(d)), the reference queries the compatibility of French law with Art. 27 EUCFR on the right to information and consultation: Case C-176/12, Association de médiation sociale v Union locale des syndicats CGT, Hichem Laboubi, Union départementale CGT des Bouche-du-Rhône, Confédération générale du travail, OJ 2012 C 184/5.

203 Some of the rights in the Revised European Social Charter might be applicable in the context of a transfer of the undertaking, e.g. Art. 21 on the right to information and consultation.

204 The Explanatory Notes accompanying the Charter do, however, link the Acquired Rights Directive with Art. 27 on the right to information and consultation and Art. 30 on protection from unjustified dismissal. See: Explanations, supra note 70.

205 Defrenne II, supra note 43.
} 
The example of equality law provides the most vivid illustration of the effects of constitutionalization. The Court has deployed constitutional equality principles to shape its interpretation of EU secondary legislation. In the past decade, however, the Court seems to be recasting this process. Constitutional rights and principles are no longer an aid to interpretation; they are the foundation of equality law, while secondary legislation is reduced to a 'mere expression' of these principles. The emphasis on the fundamental nature of the rights at stake in equality law has led the Court to stretch existing orthodoxy around the exclusion of direct effect of Directives in relation to private law relationships. Arguably, the trajectory of the Court's case law is decoupling equality law from its employment law roots. The extension of equality rights to areas outside the labour market, such as the provision of services, suggests that equality law is becoming a separate species, a nascent branch of EU human rights law.

The spreading tentacles of constitutionalization were also evident in the law surrounding the personal scope of employment rights. This topic was selected because of the absence of an obvious connection to fundamental rights. There are no clearly articulated or internationally recognized standards regarding the types of contractual or non-contractual relationships that should be regarded as falling within the scope of employment protection law. The lack of coherence is also reflected in the approach of the Court of Justice, which fluctuates depending upon the aspect of employment law under consideration. In resolving this conundrum, the Court has once again reached for constitutional principles, seeking to ensure a very broad personal scope for employment rights where the Court views these as touching upon constitutionally significant rights and principles.

The examination of the personal scope of employment rights drew out the difficulty of delimiting the effects of constitutionalization. Constitutionalization seems to be premised upon the identification of some employment rights as fundamental rights, thereby warranting a stricter standard of protection by Courts and legislators. This also implies that there are some employment rights that are not 'fundamental' in nature and where there is a greater margin of discretion to balance the objectives of social protection with those of business flexibility and competitiveness. The expansion in the list of 'fundamental' social rights, witnessed in the Council of Europe's Revised Social Charter or the EU Charter of Fundamental Rights, risks swallowing up the whole of employment law. Yet if every aspect of employment law is construed as fundamental in nature, then this dilutes the meaning or significance of what a 'fundamental' right entails. Consequently, there is a need to confront the boundaries of constitutionalization, to accept that some elements of EU employment law lie on the margins of this process. Naturally, the focus of legal innovation has been upon the discovery and exploration of fundamental social rights, such as the litigation surrounding the Working Time Directive. It is only occasionally that the Court indicates where it draws the line. In this regard, the Acquired Rights Directive emerges as one element of EU employment legislation where the existing case law does not suggest that the Court views the rights therein as fundamental in nature.

The enhanced legal status for the Charter of Fundamental of Rights since 2009 opens up a new vista for the constitutionalization of EU employment law. The array of social rights recognized within the Charter invites debate over whether, and to what extent, this will shift the contours of employment rights even further in the direction of constitutionalization. A steady stream of judgments show the Court's increasing willingness to take the Charter into account in this branch of law. ${ }^{206}$ There is a temptation for scholars

206 E.g. Zoi Chatzi, supra note 53; Danosa, supra note 11; KHS AGv Schulte, supra note 185. 
and activists to treat the Charter as an all-encompassing solution to the external pressures on employment rights arising from trends such as globalization and the current climate of economic austerity. Arguably, though, reflection is needed on distinguishing those areas of employment law where constitutionalized protection of rights adds value and is justified, and those where this is not the appropriate pathway. Taken to its logical conclusion, the emergence of a 'constitutionalized' employment contract could be imagined. ${ }^{207}$ This would consist of those minimum core rights from which neither legislatures, nor employers could derogate. The existing case law helps to map the constituent elements of such a contract, such as non-discrimination or the right to paid annual leave. Given the pressures on employment law arising from the economic crisis, the codification of a constitutionalized employment contract could offer a bulwark against a downward spiral of deregulation. 